\title{
$18: 59137025-58941558$
}

National Cancer Institute

\section{Source}

National Cancer Institute. 18:59137025-58941558. NCI Thesaurus. Code C41761.

Physical location of BCL2_Gene 